\title{
Findings of Male Genital Anomalies in a Turkish Population with Autism Spectrum Disorders
}

\author{
Otizm Spektrum Bozuklukları Olan Bir Türk \\ Popülasyonda Erkek Genital Anomalileri Bulguları
}

\begin{abstract}
Aims: Autism spectrum disorder (ASD) is a set of heterogeneous neurodevelopmental conditions, and genetics has a key role in the etiology, in connection with developmentally early environmental factors. These factors also affect the prevalence of congenital anomalies in children with ASD. This study aimed to determine the prevalence of genital anomalies in male patients with ASD in the Turkish population.

Materials and Methods: Data of 524 children with ASD aged between 11 and 316 months were examined retrospectively. The diagnosis was mostly established by clinical expression and examination, rather than assessment using the formal tools.

Results: Four hundred and thirty-two (82.4\%) of the children were male and 92 (\%17.6) were female. Only 19 of the 432 (4.4\%) boys were diagnosed with a genital anomaly. Ten of the 19 patients (52\%) was diagnosed with cryptorchidism, which was the most common genital anomaly in our study.

Discussion and Conclusion: Despite having some limitations, this study is one of the few studies with a large population that investigate the comorbidity of genital anomalies in boys with ASD in the Turkish population, and showed that male genital anomalies had a high incidence in the sample included.
\end{abstract}

Keywords: ASD; cryptorchidism; hypospadias; male genital anomalies

\section{Öz}

Amaç: Otizm spektrum bozukluğu (OSB) heterojen bir nörogelişimsel bozukluktur. Etiyolojisinde genetik ve erken dönemde maruz kalınan çevresel faktörler önemli bir rol oynar. Bu faktörler, ayrıca OSB'li çocuklarda konjenital anomalilerin prevalansını da etkiler. Bu çaış̧mada Türk toplumunda OSB'li erkek hastalarda genital anomali prevalansını saptamak amaçlanmış̧ır.

Gereç ve Yöntemler. OSB'li 11-316 aylık 524 çocuğun verileri geriye dönük olarak incelendi. OSB tanısı, genel olarak ölçüm araçları ile değil, klinik muayeneler ile konmuştu.

Bulgular: Hastaların 432'si (\%82,4) erkek, 92'si $(\% 17,6)$ kızdı. 432 (\%4,4) erkek hastanın 19'u herhangi bir genital anomaliye sahipti. Bu 19 hastanın 10'una (\%52) kriptorşidizm (çalışmamızda görülen en yaygın genital anomali) tanısı konduğu saptandı.

Tartışma ve Sonuç: Bazı limitasyonları olmakla birlikte, bu çalışma Türk toplumunda OSB'li erkek çocuklarda genital anomali komorbiditesini araştıran büyük örneklemli az sayıdaki çalışmadan biridir ve incelenen grupta erkek genital anomali insidansının yüksek olduğunu göstermiştir.

Anahtar Sözcükler. erkek genital anomalileri; hipospadias; kriptorşidizm; OSB
Sahin Bodur ${ }^{1}$, Hesna Gul ${ }^{1}$ Miray Cetinkaya²,

Candan Taskiran², Yetis Isildar²

Gulhane Research and Training Hospital, Department of Child and Adolescent Psychiatry

2 Sami Ulus Research and Training Hospital, Department of Child and Adolescent Psychiatry

Geliş/Received : 17.09.2018 Kabul/Accepted: 04.12.2018

DOI: 10.21673/anadoluklin.460738

Yazışma yazarı/Corresponding author Hesna Gul

Gulhane Research and Training Hospital, Ankara, Turkey

E-mail:drhesnagul@gmail.com

\section{ORCID}

Sahin Bodur: 0000-0002-4942-7932 Hesna Gul: 0000-0002-1696-1485 Miray Cetinkaya: 0000-0003-4795-5413 Candan Taskiran: 0000-0001-6116-2730 Yetis Isildar: 0000-0002-4885-2478 


\section{INTRODUCTION}

Autism spectrum disorder (ASD) is a neurodevelopmental disorder characterized by persistent deficits in social communication and social interaction across multiple contexts as well as restricted, repetitive patterns of behavior, interests or activities; and the symptoms cause clinically significant impairment in social, occupational or other important areas of current functioning (1). In 2014, the Centers for Disease Control and Prevention (CDC) estimated the prevalence of ASD as 1 in 68 live births, while it was 1 in 88 in 2012, 1 in 110 in 2008, and 1 in 150 in 2007, thus providing evidence of increased autism identification over time (2). Autism affects more male than female individuals, and comorbidity with other medical problems and disorders are common ( $>70 \%$ have concurrent conditions). Individuals with autism have atypical cognitive profiles, such as impaired social cognition and social perception, executive dysfunction, and atypical perceptual and information processing.

Despite the significant advances during the past decades, the etiology of ASD is still unclear. It is known that symptoms are the consequences of underpinned atypical neural development. ASD has been positively associated with numerous chromosomal abnormalities, gene variants including single and/or larger copy number variants comprising both inherited and de novo mutations and genetic syndromes $(3,4)$. On the other hand, the composite evidence supports a complex polygenic risk and gene-environment interactions. The prenatal period is probably the most critical time frame for the nongenetic risk factors of ASD. While the biological mechanisms are not completely understood, research to date points to several general areas of interest, and one of the most important in these areas is an endocrine disruption (5-7).

As is known, androgens play important roles in the development of the urethra and external genitalia in boys. In addition, testosterone is well-known for its role as a sex-related biological mechanism and affects these conditions and domains of functioning. Developmentally, testosterone may sex-differentially impact fetal brain development by influencing early neuronal development and synaptic mechanisms behind cortical circuit formation, particularly for circuits that later develop specialized roles in such cognitive domains.
In a recent study, authors found that variation in fetal testosterone (FT) exerted sex-specific effects on later adolescent functional connectivity between social brain default mode network (DMN) subsystems. Increased FT is associated with dampening of functional connectivity between DMN subsystems in adolescent males, but has no effect in females (8). The role of androgens in the ASD etiology has been proposed based on the participation of sex hormones in the regulation of communication and social interactions and the involvement of several genes that regulate sex hormone pathways in ASD pathogenesis (9-12). Also, androgen deficiency leads to the development of cryptorchidism (undescended testes) and hypospadias (abnormal positioning of the urethral opening), which are among the most common genital birth defects in males and are strongly associated with prenatal androgen deficiencies. An increasing prevalence of these anomalies has been reported over time $(13,14)$, and also several studies have demonstrated that ASD is associated with a higher rate of congenital anomalies based on androgen hormone problems (15-17).

Thus, a better understanding of the connection between ASD and congenital anomalies could have implications, both for understanding the ASD etiology and for generating interventions to reduce its symptoms. In this study, our aim was to examine the link between androgen-dependent male reproductive system abnormalities and ASD, exploring the association between hypospadias, cryptorchidism, and ASD in a large clinical sample from Turkey.

\section{MATERIALS AND METHODS}

We conducted retrospective chart reviews of 524 children diagnosed with ASD at the Child and Adolescent Psychiatry Clinic of the Dr. Sami Ulus Research and Training Hospital, Ankara, Turkey, between June 2010 and June 2014. The study was carried out in accordance with the Declaration of Helsinki, after approval by the Hospital's ethics committee (2014, no. 73799008).

At the Dr. Sami Ulus Research and Training Hospital, all children are examined in the general pediatric clinic, in consultation with the other departments according to their medical examination. The ASD diagnosis used in this study was based on (i) physical, neu- 
rological, and developmental assessment conducted by a pediatric psychiatrist, (ii) fulfillment of all Diagnostic and Statistical Manual of Mental Disorders ( $4^{\text {th }}$ or $5^{\text {th }}$ ed.) criteria, and (iii) an additional independent psychological assessment that includes a detailed, ageappropriate developmental and cognitive evaluation confirming the diagnosis of ASD. Additional observations from speech pathologists, occupational therapists, and social workers were incorporated into the process, if necessary. The children in our sample were also examined by a child neurologist, ophthalmologist, physiotherapist, and pediatric surgery and genetics professionals. Pediatric surgery and urology evaluations included provision of surgical services when necessary and requested. Genetic evaluations included specific molecular analyses for etiological diagnosis, if necessary. We obtained the data from the 524 patients' records, including age, sex, general medical history, and psychiatry findings.

Psychiatric evaluations included clinical interviews and play sessions to determine the ASD symptoms. Interviews were conducted separately with children and their parents by a child and adolescent psychiatrist. Clinical interviews with parents included questions regarding demographic information, ASD history, and the emotional or behavioral problems observed in the children.

\section{Statistical analysis}

Descriptive analyses were applied to all variables, and Pearson's X2 and Fisher's exact tests and contingency table analysis were performed to compare categorical variables, by using SPSS 20.0 for Windows. A $5 \%$ type- 1 error level was used to infer statistical significance.

\section{RESULTS}

Data of a total of 524 children aged between 11 and 316 months with ASD were examined. The diagnosis of ASD was predominantly based on clinical expression rather than assessment using the formal tools. Four hundred thirty-two (82.4\%) of the children were male and 92 (\%17.6) were female. Only 19 of the 432 (4.4\%) boys were diagnosed with a genital anomaly. Ten of the 19 patients (52\%) were diagnosed with cryptorchidism, which was the most common genital anomaly in our study. The age of diagnosis of cryptorchidism was presented in Table 1, and Table 2 show the other genital problems observed in the male patients with ASD.

\section{DISCUSSION AND CONCLUSION}

Our results demonstrated that the prevalence of genital anomalies was $13.4 \%$ in this clinical ASD sample from Turkey. The most common in these anomalies was cryptorchidism.

Cryptorchidism is a developmental defect marked by the failure of one or both of the testes to descend into the scrotum from the abdomen and is a common congenital malformation affecting an estimated 2-9\% of male infants (13). At the age of 1 year, the incidence is $1 \%$, because most of them will descent spontaneously (18). Authors recommended that orchiopexy should be done at 6-12 months of age because the risk of infertility and cancer increases with increasing age at the time of orchiopexy (19). Hypospadias is also relatively common, the mean prevalence estimates varying from 5.2-34.2 per 10,000 live births in America (20). The true prevalence is difficult to estimate because of the extremely broad severity of the defect and the high prevalence of mild or glandular forms that may not be recognized in the early years of life (21). According to the male predominance in the prevalence of ASD, it is important to study perinatal factors affecting male births. Moreover, both genetic and endocrine-related factors are implicated in the etiology of ASD, hypospadias, and cryptorchidism. In our study 10 of the 19 patients with male genital anomalies (52\%) were diagnosed with cryptorchidism, the age of diagnosis ranging from 1 to 177 months. Unfortunately, it was too late to prevent further complications. The literature contains many studies investigating children with ASD for comorbidity with other conditions such as psychiatric disorders, gastrointestinal disorders, sleep disorders, and epilepsy (22). Genital anomalies could be overlooked, because these comorbidities are wellestablished and have more noticeable symptoms.

As is known, congenital malformations of the male reproductive system are associated with several neurodevelopmental disorders across the lifespan $(23,24)$. In a recent cross-sectional study, analysis of 105 million 
US health insurance records showed that ASD and intellectual disability (ID) risk increased in males with male congenital malformations including undescended testicles, hypospadias, epispadias, micropenis, congenital chordees, and unspecified malformations (24). A supporting, nationwide matched cohort study from Sweden showed that males with hypospadias had higher risks of ID, ASD, attention deficit hyperactivity disorder (ADHD), and other behavioral/emotional disorders than males without hypospadias (23). Also, they found that the unaffected brothers of the hypospadias patients also had an increased risk of ASD. Evidence concerning cryptorchidism and risk of longterm neurodevelopmental disorders was limited up to 2018. To this date, two small sample studies described a high proportion of cryptorchidism among hospitalized males with cerebral palsy and mental retardation (25-28).

Similar results were found for cryptorchidism by Chen et al. in 2018 (17). They also observed that risks were higher in boys with bilateral vs unilateral cryptorchidism for intellectual disability, ASD, and ADHD, suggesting a dose-response relationship. Results of the recent studies suggested that the relationship between ASD and male genital anomalies could be associated with common familial genetic or environmental factors during early embryogenesis $(17,23,24)$. The high prevalence of male genital anomalies found in our study are consistent with the findings reported in the mentioned studies.

Our study has some limitations. Firstly, due to retrospective design, perinatal history could not be detailed and we did not use clinical scales for the evaluation of the children and families. Secondly, we could not document the prevalence of genital anomalies in the girls with ASD because of the paucity of their medical records; the relationship between the female reproductive system anomalies and neurodevelopmental disorders should be addressed in future studies. Elucidating the relationship between male and female genitourinary tract malformations and ASD, the effect of androgens on this relationship are potentially important to furthering our understanding of the underlying causes of ASD.

In conclusion, ASD is a prevalent developmental disorder. Studies indicate that while the etiology has
Table I. Cryptorchidism in the patients with ASD

\begin{tabular}{|c|c|}
\hline Case number & Diagnosis age (months) \\
\hline 1 & 1 \\
\hline 2 & 102 \\
\hline 3 & 177 \\
\hline 4 & 15 \\
\hline 5 & 19 \\
\hline 6 & 33 \\
\hline 7 & 11 \\
\hline 8 & Unknown \\
\hline 9 & 99 \\
\hline
\end{tabular}

Table II. Other genital problems observed in male patients with ASD

\begin{tabular}{|c|c|c|}
\hline Case number & Diagnosis & Diagnosis age (months) \\
\hline 10 & Hypospadias & 13 \\
\hline 11 & Hypospadias & 30 \\
\hline 12 & Hydrocele & 53 \\
\hline 13 & Hydrocele & 1 \\
\hline 14 & Anorchism & Unknown \\
\hline 15 & Macroorchidism & 106 \\
\hline 16 & Micropenis & 143 \\
\hline 17 & Micropenis & Unknown \\
\hline 18 & Hypospadias & 10 \\
\hline 19 & Hydrocele & 3 \\
\hline
\end{tabular}

a genetic component, the risk is polygenic, and geneenvironment interactions are also important. The prenatal period is a possible critical exposure window for nongenetic risk factors of ASD. To date, studies have found positive associations between congenital malformations and ASD; a few also found specific associations between genitourinary system malformations. This study showed that cryptorchidism is also higher among boys with ASD than in the normal Turkish population. The increased risks for neurodevelopmental disorders in cryptorchid boys may be due to shared genetic or in utero/early postnatal risk factors, rather than to cryptorchidism itself. Moreover, even though the underlying mechanisms are yet unknown, the findings reported in this study have implications for the follow-up of boys born with genitourinary malformations who might have subsequent developmental delays, potentially with early symptoms of ASD. It should also be noted that preventive health services are more cost-effective and early treatment of malignancies are more satisfactory. Therefore, all boys as well as chil- 
dren with ASD should be examined routinely through childhood, and genital conditions should also be taken into account. Despite having some limitations, this study is one of the few studies with a large population that investigate the comorbidity of genital anomalies in boys with ASD. Children with ASD require broad multidisciplinary management for the timely, comprehensive, and accurate treatment of the possible comorbidities.

\section{Statement of Conflict of Interest}

The authors have no conflict of interest to declare.

\section{REFERENCES}

1. Association AP. Diagnostic and statistical manual of mental disorders (DSM-5). American Psychiatric Pub. 2013.

2. Monteiro SA, Spinks-Franklin A, Treadwell-Deering D, Berry L, Sellers-Vinson S, Smith E, et al. Prevalence of autism spectrum disorder in children referred for diagnostic autism evaluation. Clin Pediatr. 2015;54(14):1322-7.

3. Rosti RO, Sadek AA, Vaux KK, Gleeson JG. The genetic landscape of autism spectrum disorders. Dev Med Child Neurol. 2014;56(1):12-8.

4. Vijayakumar NT, Judy M. Autism spectrum disorders: Integration of the genome, transcriptome and the environment. J Neurol Sci. 2016;364:167-76.

5. Modabbernia A, Velthorst E, Reichenberg A. Environmental risk factors for autism: an evidence-based review of systematic reviews and meta-analyses. Mol Autism. 2017;8(1):13.

6. Ornoy A, Weinstein-Fudim L, Ergaz Z. Genetic syndromes, maternal diseases and antenatal factors associated with autism spectrum disorders (ASD). Front Neurosci. 2016;10:316.

7. Arndt TL, Stodgell CJ, Rodier PM. The teratology of autism. Int J Dev Neurosci. 2005;23(2-3):189-99.

8. Lombardo MV, Auyeung B, Pramparo T, Quartier A, Courraud J, Holt RJ, et al. Sex-specific impact of prenatal androgens on intrinsic functional connectivity between social brain default mode subsystems. BioRxiv. 2018:253310.

9. Chakrabarti B, Dudbridge F, Kent L, Wheelwright S, HillCawthorne G, Allison C, et al. Genes related to sex steroids, neural growth, and social-emotional behavior are associated with autistic traits, empathy, and Asperger syndrome. Autism Res. 2009;2(3):157-77.

10. Schmidtova E, Kelemenova S, Celec P, Ficek A, Ostat- nikova D. Polymorphisms in genes involved in testosterone metabolism in Slovak autistic boys. The Endocrinol. 2010;20(5):245-9.

11. Zettergren A, Jonsson L, Johansson D, Melke J, Lundström S, Anckarsäter $\mathrm{H}$, et al. Associations between polymorphisms in sex steroid related genes and autistic-like traits. Psychoneuroendocrinol. 2013;38(11):2575-84.

12. Miodovnik A, Diplas AI, Chen J, Zhu C, Engel SM, Wolff MS. Polymorphisms in the maternal sex steroid pathway are associated with behavior problems in male offspring Psychiatr Genet. 2012;22(3):115.

13. Toppari J, Virtanen HE, Main KM, Skakkebaek NE. Cryptorchidism and hypospadias as a sign of testicular dysgenesis syndrome (TDS): environmental connection. Birth Defects Res A Clin Mol Teratol. 2010;88(10):9109.

14. Skakkebaek NE, Rajpert-De Meyts E, Buck Louis GM, Toppari J, Andersson AM, Eisenberg ML, et al. Male reproductive disorders and fertility trends: influences of environment and genetic susceptibility. Physiol Rev. 2015;96(1):55-97.

15. Timonen-Soivio L, Vanhala R, Malm H, Leivonen S, Jokiranta E, Hinkka-Yli-Salomäki S, et al. The association between congenital anomalies and autism spectrum disorders in a Finnish national birth cohort. Dev Med Child Neurol. 2015;57(1):75-80.

16. Schieve LA, Shapira SK. Invited Commentary: male reproductive system congenital malformations and the risk of autism spectrum disorder. Am J Epidemiol 2018;187(4):664-7.

17. Chen J, Sørensen HT, Miao M, Liang H, Ehrenstein V, Wang Z, et al. Cryptorchidism and increased risk of neurodevelopmental disorders. J Psychiatr Res. 2018;96:153-61.

18. Sijstermans K, Hack W, Meijer R, van der Voort-Doede$\mathrm{ns} \mathrm{L}$. The frequency of undescended testis from birth to adulthood: a review. Int J Androl. 2008;31(1):1-11.

19. Chan E, Wayne C, Nasr A. Ideal timing of orchiopexy: a systematic review. Pediatr Surg Int. 2014;30(1):87-97.

20. Springer A, Van Den Heijkant M, Baumann S. Worldwide prevalence of hypospadias. J Pediatr Urol 2016;12(3):152.e1-e7.

21. Boisen K, Chellakooty M, Schmidt I, Kai C, Damgaard I, Suomi AM, et al. Hypospadias in a cohort of 1072 Danish newborn boys: prevalence and relationship to placental weight, anthropometrical measurements at birth, and reproductive hormone levels at three months of age. J Clin Endocrinol Metab. 2005;90(7):4041-6.

22. Kohane IS, McMurry A, Weber G, MacFadden D, Rap- 
paport L, Kunkel L, et al. The co-morbidity burden of children and young adults with autism spectrum disorders. PloS one. 2012;7(4):e33224.

23. Butwicka A, Lichtenstein P, Landén M, Nordenvall AS, Nordenström A, Nordenskjöld A, et al. Hypospadias and increased risk for neurodevelopmental disorders. J Child Psychol Psychiatry. 2015;56(2):155-61.

24. Rzhetsky A, Bagley SC, Wang K, Lyttle CS, Cook Jr EH, Altman RB, et al. Environmental and state-level regulatory factors affect the incidence of autism and intellectual disability. PLoS Comput Biol. 2014;10(3):e1003518.
25. Cortada X, Kousseff BG. Cryptorchidism in mental retardation. J Urol. 1984;131(4):674-6.

26. Rundle J, Primrose D, Carachi R. Cryptorchism in cerebral palsy. Brit J Urol. 1982;54(2):170-1.

27. Depue RH. Cryptorchidism, an epidemiologic study with emphasis on the relationship to central nervous system dysfunction. Teratol. 1988;37(4):301-5.

28. Liederman J, Flannery KA, Curley J. Cryptorchidism (undescended testes): a common congenital malformation associated with neurobehavioral abnormalities. Child Neuropsychol. 1997;3(2):134-46. 